\title{
Special Issue Editorial: Dancing with Custom
}

This special issue of the International Community Law Review is dedicated to an evergreen of public international law doctrine, namely the identification of customary international law. This topic remains a hotly debated and polarizing issue in international law doctrine, ${ }^{1}$ in particular because custom endures as an elusive source that stands in stark contrast to written and therefore more tangible treaties. And even though the familiar additive understanding of custom as consisting of the two elements of practice plus opinio juris is now considered to be axiomatic or orthodox, ${ }^{2}$ it remains a troubled concept that has come under heavy fire during the last couple of decades. ${ }^{3}$ In this respect, this special issue intends to catch two birds with one stone and not only draw the readers' attention to the ILC's Draft Conclusions on Identification of Customary International Law (2018), ${ }^{4}$ which discusses the traditional two-elements approach of Article 38 of the ICJ Statute, but also to engage with Jean d'Aspremont's critical debate of new approaches to the identification of customary international law, published in 2014 on the EJILTalk! Blog entitled 'Customary International Law as a Dancefloor'.5 In this contribution, d'Aspremont admits that this traditional additive understanding is not without problems, but he criticises that simply tossing out these theoretical

1 See e.g., Omri Sender and Michael Wood, 'Custom's Bright Future:The Continuing Importance of Customary International Law' in Curtis A. Bradley (ed.), Custom's Future: International Law in a Changing World (Cambridge: Cambridge University Press, 2016) 360-370.

2 See David Lefkowitz, 'Sources in Legal-Positivist Theories: Law as Necessarily Posited and the Challenge of Customary Law Creation', in Samantha Besson and Jean d'Aspremont (eds.), The Oxford Handbook on the Sources of International Law (Oxford: Oxford University Press, 2017) 330 .

3 See Gerald J. Postema, 'Custom in International Law: A Normative Practice Account' in Amanda Perreau-Saussine and James Bernard Murphy (eds.), The Nature of Customary Law (Cambridge: Cambridge University Press, 2007) 279-281.

4 Adopted by the International Law Commission at its seventieth session, in 2018, and submitted to the General Assembly as a part of the Commission's report covering the work of that session (A/73/10, para. 65). The report will appear in Yearbook of the International Law Commission, 2018, vol. II, Part Two.

5 Jean d'Aspremont, Customary International Law as a Dance Floor: Part I, EJIL Talk!, 14 April 2014 (https://www.ejiltalk.org/customary-international-law-as-a-dance-floor-part-i/); and Jean d'Aspremont, Customary International Law as a Dance Floor, Part II, EJIL Talk!, 15 April 2014 (https://www.ejiltalk.org/customary-international-law-as-a-dance-floor-part-ii/). 
constraints turns customary international law in a dance floor where almost anything goes. It is with good reason that such a move cannot resolve the continuing problems in identifying customary international law.

This special issue assembles reactions to Jean d'Aspremont's contribution of 2014, starting with first dancing lessons and theoretical approaches to the identification of customary international rules. D'Aspremont himself leads off the dance with his own retelling of the story of the doctrine of customary international law between the drafting of rules to be applied by the then-newly established Permanent Court of International Justice in 1920 and the ILC's adoption of 16 conclusions on the identification of customary international law in 2018 ('The Four Lives of Customary International Law'). These first dancing lessons then continue with Matthias Lippold's 'Reflections on Custom Critique and on Functional Equivalents in the Work of d'Aspremont' which relates his critique to scholarship and critiques the distinction between ascertainment and content-determination of customary law. Fernando Bordin takes a very optimistic stance in his contribution 'A Glass Half Full? The Character, Function and Value of the Two-Element Approach to Identifying Custom'; whereas Michael Wood finishes with questions on 'Customary International Law and the General Principles of Law Recognized by Civilized Nations'.

After these first theoretical dancing lessons, Magdalena Pacholska inaugurates the second part of this special issue and the great ball night with a rather modern boy-band reminiscence entitled 'New Kids on the Block: International Organizations as Customary Rules Creators'. Kasey McCall-Smith then continues the dance with 'Treaty Bodies: Choreographing the Customary Prohibition against Torture' and the question to which extent human rights treaty bodies can contribute to the development of customary international law, while Agata Kleczkowska concludes the ball night with her topical contribution on 'Changing Customary Law: The Shape of the Prohibition of the Use of Force after the 2017 and 2018 Airstrikes in Syria.'

Let the dance begin; alles Walzer.

\author{
Paul Gragl \\ Reader in Public International Law and Theory at Queen Mary, \\ University of London, Department of Law \\ p.gragl@qmul.ac.uk
}

